\title{
Selection Of Shipping Services Using Analytical Hierarchy Process (AHP) Methods
}

\author{
Dzakiyah Agustin Puspitasari', Febriola Rania Trihelmina ${ }^{1}$, Maya \\ Kencana Wulandari ${ }^{1}$, Anindiatie Parastikasari ${ }^{1}$, and Hidayatul Khusna ${ }^{{ }^{*}}$ \\ ${ }^{1}$ Department of Statistics, Faculty of Science and Data Analytics, Institut Teknologi Sepuluh Nopember \\ *Corresponding author: hidayatul@its.ac.id
}

Received: 25 September 2021 Accepted: 27 September 2021

\begin{abstract}
Online business has come along way since these early days, where people can purchase items from the comfort of their own homes and workplace. This causes people to choose to shop online rather than go to offline store, thus, the freqeuncy of delivery services keep getting higher day by day. In determining the right shipping service, every people has a different needs. This study aims to identify factors that affect customers in choosing shipping services. The variable includes threedimension which are alternative, criteria, and sub-criteria. The number of respondents for this study is 72 . Four major shipping service companies in Indonesia were selected to be the alternativeincludes JNE, J\&T, SiCepat and Pos Indonesia. The analysis shows that there are 5 criteria and $2 \mathrm{sub}$ criteria for each criterion, that can be used to measure user preference of choosing shipping services. In this study it was found that the value of consistency ratio in each matrix paired is $\odot 0,1$ so that the AHP method in this study has optimal results. From the analysis, each criterion was weighted to rank the customers preference of choosing a shipping service relatively of each other. The best delivery service selected is J\&T with the criteria sorted from most important to least important are security, quality of service, price, area coverage and distance.
\end{abstract}

Keywords- Analytical Hierarchy Process (AHP), Consistency Index, Consistency Ratio, Criteria, Shipping Services

\section{INTRODUCTION}

Online business has become a trend and necessity intoday's times. There are many options that can be used by people who does business or the general public to ship theirgoods. In Indonesia, there are various kinds of shipping ordelivery services, such as JNE, J\&T, Pos Indonesia, and SiCepat. Of the four service providers, a decision support system is needed to select the best shipping services used by the Indonesian people.

AHP is an ideal method to provide an alternative ranking/order when the criteria for making decisions vary widely [1]. Saaty (1970) developed a strong and helpful tool for managing qualitative and quantitative multi-criteria elements involving in decision-making behavior by prioritizing severalalternatives by considering several criteria and allows decision makers to arrange problems into an integrated hierarchy or series of levels, then enter numerical values as a substitute for human perception in making comparisons. Furthermore, these values are processed systematically to produce logical priorities [1]. AHP is often used in solving problems of alternative determination, priority setting, policy selection, optimization, and performance measurement [1].

Several criteria that are influential and commonly used inthe selection of shipping service companies include price criteria with sub-criteria for affordable prices and high prices, distance of shipping with sub criteria close to work place and close to home, criteria for safe shipping process with sub- criteria for unbroken goods and goods are not wet during the delivery process, area coverage with sub-criteria for deliveryto the island of Java and national delivery, criteria for service quality with sub-criteria for service provider responsiveness and timeliness of goods to the recipient. In the AHP method, the criteria are usually arranged in a hierarchical form. The criteria in this study are the criteria used by service users in choosing a shipping service company. Election issues are organized into three hierarchical levels. At the highest level of the hierarchy, stated goals, objectives of the system for which the solution is sought. The next level is the elaboration of these objectives, namely the criteria that must be considered inmaking decisions. The lowest level is the alternative choice that will be selected [1].

Kotler revealed that there are five dominant factors or determinants of service quality, namely tangible, reliability, responsiveness, assurance, empathy [2]. However, according to Tjiptono there are ten main factors that determine the quality of service that can be used in the analysis, including reliability, responsiveness, competence, access, politeness, communication, credibility, understanding [3]. In addition to the ten main factors that determine the quality of services above, based on some literature there are criteria that are most influential in choosing a shipping service company, namely the price criteria. Price is the amount of money that must be paid by customers who want to get a good or service [2]. 


\section{THEORETICAL BACKGROUND}

\section{A. Descriptive Statistics}

Descriptive statistics are specific methods basically used to calculate, describe, and summarize collected research data in a logical, meaningful, and efficient way. Descriptive statistics are reported numerically in the manuscript text and/or in its tables, or graphically in its figures [4].

One of the charts used to interpret descriptive statistics is the pie chart. Pie charts are designed to visualize how a whole is divided into various parts. Each segment of the pie is a particular category within the total data set. In this way, it represents a percentage distribution.

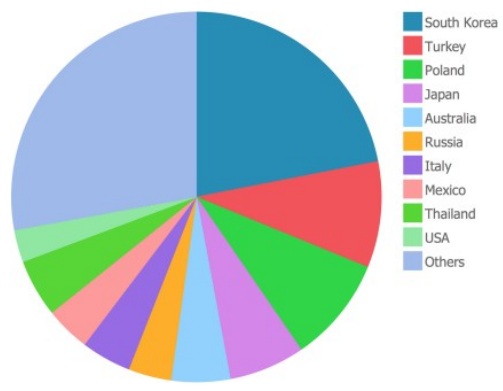

Figure 1. Pie Chart

\section{B. Purposive sampling}

Purposive sampling is a non-probability sampling method. Purposive sampling is a sampling technique with certain considerations. Nonprobability sampling is sampling technique that does not give equal opportunities / opportunities for every member or members of the population for selected to be the sample.

\section{Analysis Hierarchy Process}

The AHP is a general measurement theory that depends onthe values and judgments of individuals and groups. Moreprecisely, judgments are brought together according to a multilevel hierarchic structure that allows deriving priorities. The major advantage of the hierarchical structure is that it allows for a detailed, structured and systematic decomposition of the overall problem into its fundamental components and interdependencies, with a large degree of flexibility. The AHP has found its widest applications in multi-criteria decision making, in planning and resource allocation and in many otherfields [6]. To make a decision in an organized way to generate priorities we need to decompose the decision into the following steps:

1. Define the problem and determine the kind of knowledge sought.

2. Structure the decision hierarchy from the top with the goal of the decision, then the objectives from a broad perspective, through the intermediate levels (criteria onwhich subsequent elements depend) to the lowest level (which usually is a set of the alternatives).

3. Construct a set of pairwise comparison matrices.

Each element in an upper level is used to compare the elements in the level immediately below with respect to it. Use thepriorities obtained from the comparisons to weigh the priorities in the level immediately below. Do this for every element. Then for each element in the level below add its weighed values and obtain its overall or global priority. Continue this process of weighing and adding until the final priorities of the alternatives in the bottom most level are obtained. To make comparisons, we need a scale of numbers that indicates how many times more important or dominant one element is over another element with respect to the criterion or property with respect to which they are compared [7].

The following is steps to analysis with Analysis Hierarchy Process [8]:

1. Construct the model and restructuring problem. Model construction is based on problems, so it needs to be done clearly

2. Paired comparison matrix indicates a connection. Comparison pairing on the AHP is carried out by comparing the importance of each element the criteria for control.

3. Determines the eigen value of the matrix. Calculate eigen vector by summing the value of each column of matrix then divides each value column cell with column totals and sums values of each row and divided $n$.

\section{Logistics}

Logistics is the strategically managing the procurement, movement, and storage of materials, parts and finished inventory (and the related information flows) through the organization and its marketing channels in such a way that current and future profitability are maximized through the cost-effective fulfillment of orders [9]. 


\section{E. Logistic Service}

In the implementation of logistics services, conventionally is just an activity that transfers products for consumption. However, in the mid-1990s, this concept changed namely with the existence of logistics services companies that expected to be able to provide quality services and generate customer satisfaction greater loyalty and also creates greater loyalty users of logistics services [10].

\section{F. Shipping Service}

A shipping delivers messages, packages, and mail. Shipping are distinguished from ordinary mail services by features such as speed, security, tracking, signature, specialization and individualization of express services, and swift delivery times, which are optional for most everyday mail services. As a premium service, shipping are usually more expensive than standard mail services, and their use is typically restricted to packages where one or more of these features are considered important enough to warrant the cost.

Types of shipping services:

\section{Same-day Deliveries}

Within 24 hours, the items are sent and received. Either online or by phone, they can collect your parcel and drive straight to the destination, with only your item on the vehicle. Think of the convenience it brings that is similar to having a personal driver take you anywhere. Companies that sign up for this usually transact with legal matters, or where paperwork and contracts must be prepared, signed, and handled fast to meet the day's deadline. If timeliness is what you require, then this kind of service suits you.

\section{Next-Day Deliveries}

Your parcel is designated to the entity's branch and from there, it will be sent out through one of their fleets. Such an option is cheaper since the carrier works on a mass volume basis. If you would like to save on labour costs, go for this type of carting.

\section{International Services}

One or two people personally travel to the destination and deliver the shipment. These international shipping add a more personal touch. They don't have to send an item overnight, but they do get to take a paid trip at a moment's notice anywhere. So, if you're looking for someone to watch over a fragile overseas package, choose this kind of service [11].

\section{METHODS}

\section{A. Type of research}

This research is a case study which begins with finding and determining criteria for selecting alternative shipping services. the next step is to choose an alternative in the form of an shipping service brand that is familiar to the respondents. Then create a questionnaire to compare the criteria to get the criteria that most influence the choice of shipping services.

\section{B. Variables}

Research variables in this project are as follows:

1. Criteria

The criteria for selecting alternatives on shipping services are:

a. Price

The price criteria are determined to measure the respondent's interest based on the price set by the shipping service.

Divided into 2 sub criteria, namely affordable prices and high prices.

b. Distance

Distance criteria are divided into 2 sub-criteria, namely close to the workplace and close to home. The aim is to determine the respondent's interest based on the location of the shipping service.

c. Safety

The safety criteria are divided into 2 sub criteria, namely not broken and not wet. The aim is to find out the respondent's interest based on the safety of the shipping services.

d. Service Quality

Service quality is divided into 2 sub criteria, namely responsibility and on time delivery. This aims to determine the respondent's interest based on the services of the shipping service.

e. Area Coverage

The coverage area is divided into serving the island of Java and serving shipments to nationwide. 


\section{Alternative}

The alternatives chosen were several shipping services in Indonesia that were familiar among respondents, including:

a. JNE

b. J\&T

c. SiCepat

d. Pos Indonesia

\section{Variable Measurements}

The method used in selecting alternative shipping servicesis Analytical Hierarchy Process (AHP). This is done by changing the respondents' perceptions into numerical form with the help of a predetermined qualitative comparison scale [7].

Table 1. Scale for Comparison

\begin{tabular}{cc}
\hline Scale & Table 1. Scale for Comparison \\
\hline 1 & Equal importance \\
3 & Moderate importance of one factor over another \\
5 & Strong or essential importance \\
7 & Very strong importance \\
9 & Extreme importance \\
$2,4,6,8$ & Values for inverse comparison \\
\hline
\end{tabular}

\section{Collecting the Data}

1. Questionnaire

Questionnaires were distributed online to respondents. Data collection was conducted from 21 December 2020 until 28 December 2020. The questionnaire contains questions to determine priority criteria, sub-criteria, and alternatives in the selection of shipping services.

2. Literature Review

Literature study is a method used to find theories and concepts that are used as a theoretical basis for research carried out.

\section{E. Population, Sample, and Sampling Technique}

The population of this research is undergraduate students majoring in Statistics, Institut Teknologi Sepuluh Nopember class of 2018. Sampling was conducted by purposive sampling with the help of the Isaac and Michael equation. It is known that the total population is 88 students, so with a significance level of $5 \%$, the number of samples that must be taken is as many as 72 undergraduate students.

\section{F. Analysis Steps}

The analysis steps in the making of this project report areas follows:

1. Determine the background of the problem in thecompletion of a business decision analysis course project.

2. Determine of respondents.

3. Conduct literature review.

4. Determine criteria for level 1, sub criteria for level 2, andalternatives for level 3.

5. Creating a hierarchical model between attributes

6. Make of AHP questionnaire.

7. Distributing of questionnaires.

8. Make hierarchical analysis calculations

a. Create a comparison matrix

b. Calculate the partial weight of each variable with anormalized matrix.

c. Calculate the consistency ratio.

d. Calculates the consistency index.

e. Calculate the accumulated weight of each level.

9. Determine alternatives/choice.

10. Conclusions. 


\section{RESULTS AND ANALYSIS}

\section{A. Descriptive Statistics}

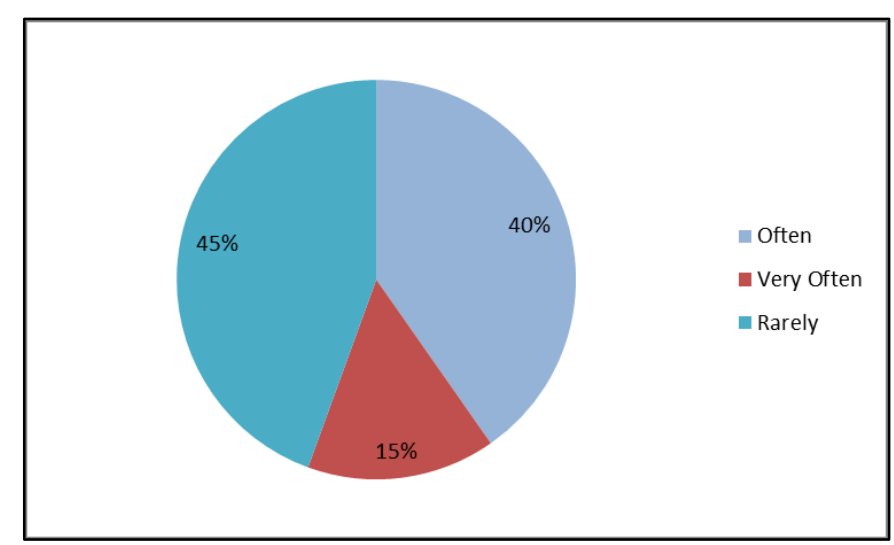

Figure 1. Pie Chart of Frequency Use of Shipping Services

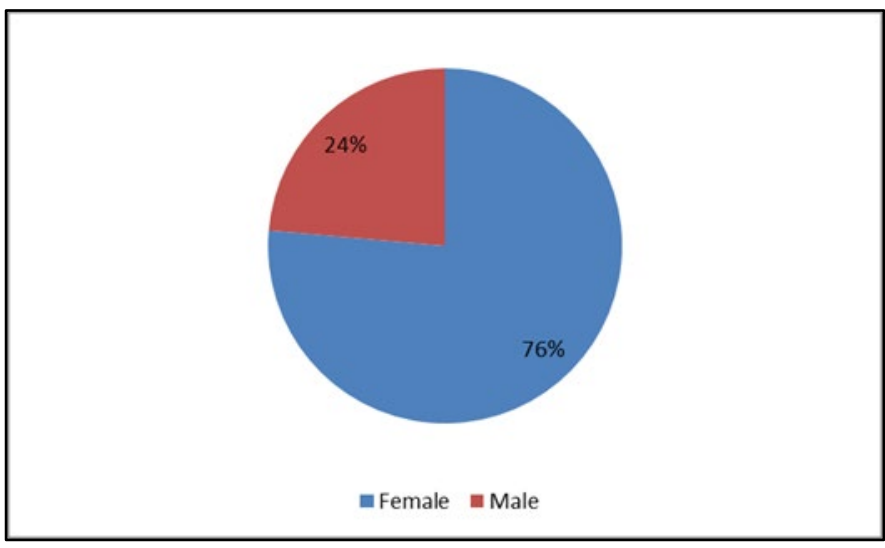

Figure 2. Pie Chart Frequency Gender of Respondents

From those figures it can be known that of the 72 respondents, $45 \%$ of them rarely use shipping services, $40 \%$ often use shipping services, and the remaining $15 \%$ very often. As a whole, $55 \%$ of respondents fall into the category often and very often. And from the picture can be known that all respondents have used shipping services with different frequencies.

From the picture above, it can be known that more than $50 \%$ of respondents are women. And the rest, as many as $24 \%$ are men. This does not indicate specific circumstances because the sample was taken with random system without considering gender homogeneity.

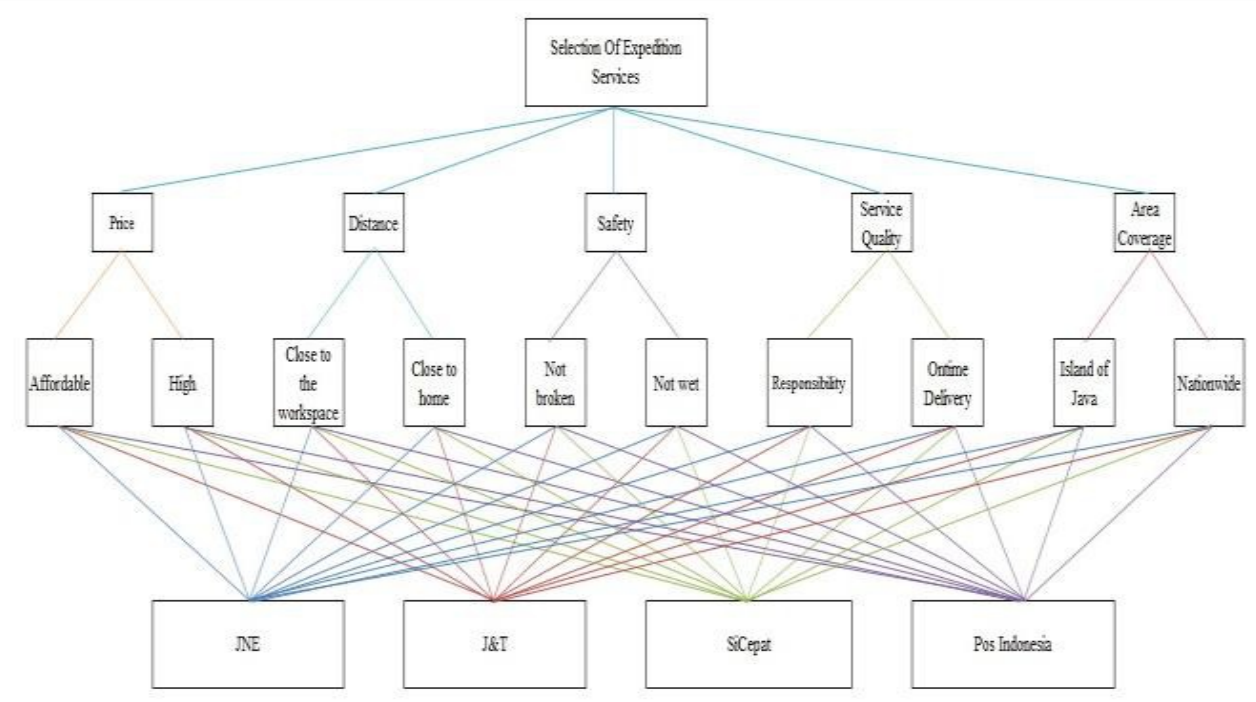

Figure 3. Hierarchy Structure of Selection Shipping Services 


\section{B. Hierarchy Structure}

The hierarchical structure of this study was based on the identification of factors that influenced the selection of alternative shipping services. The following is a hierarchical model of decisions in this study. Hierarchical structure above shows that at level 1 shows the purpose of this research is to determine the alternative selection of shipping services. Then at level 2 are the criteria that influence the selection of alternatives where these criteria are obtained from the results of discussions between researchers in this study. At level 3 are the alternatives chosen and adjusted to the target respondents, namely JNE, J\&T, SiCepat, and Pos Indonesia.

\section{Consistency Ratio Test}

The Consistency of using AHP method must be maintained sothat the resulting solution is optimal. To find out the level of consistency, the observation of AHP method is measured by the amount of consistency index. The consistency ratio and index shown in the table below.

\begin{tabular}{|c|c|c|}
\hline Pairwaise Matrix & $\mathrm{CI}$ & $\mathrm{CR}$ \\
\hline Criteria & 0,031408 & 0,028043 \\
\hline \multicolumn{3}{|c|}{$\begin{array}{c}\text { Sub } \\
\text { Criteria }\end{array}$} \\
\hline Price & 0 & 0 \\
\hline Distance & 0 & 0 \\
\hline Safety & 0 & 0 \\
\hline Service Quality & 0 & 0 \\
\hline Area Coverage & 0 & 0 \\
\hline \multicolumn{3}{|c|}{ Alternative } \\
\hline Affordable & 0.062487 & 0.06943 \\
\hline High & 0.024083 & 0.026759 \\
\hline Close to the workspace & 0.01167 & 0.012966 \\
\hline Close to home & 0.003223 & 0.003581 \\
\hline Not broke & 0.014084 & 0.015649 \\
\hline Not wet & 0.010476 & 0.01164 \\
\hline Responsibility & 0.002587 & 0.002874 \\
\hline Ontime delivery & 0.015439 & 0.017154 \\
\hline Island of Java & 0.011795 & 0.013106 \\
\hline Nationwide & 0.002722 & 0.003024 \\
\hline
\end{tabular}

Based on Table 2 it can be seen that from all matrix pairs level 1 to level 3 has a consistency value are less than 0.1 which indicates sufficient consistency for decision. It can be concluded that the degree of consistency obtained from 72 respondents are trustworthy results, meaning that the AHP method has an optimal solution to estimate Statistics ITS 2018 students decisions of selecting shipping services.

\section{Weights and Rankings Based on Main Criteria for Selecting Alternatives on Shipping Services}

This study uses 5 criteria to choose shipping services, in each criterion is calculated eigen value obtained from the value of level 1 weight, the ranking list shown in Table 3 below.

\begin{tabular}{|c|c|c|}
\hline Criteria & $\begin{array}{l}\text { Eigen } \\
\text { Vector }\end{array}$ & Rank \\
\hline Safety & 0.420745 & 1 \\
\hline Service Quality & 0.21177 & 2 \\
\hline Price & 0.168819 & 3 \\
\hline Area Coverage & 0.122701 & 4 \\
\hline Distance & 0.075965 & 5 \\
\hline
\end{tabular}

Based on the analysis of eigen value obtained from the value of level 1 weight that shown in Table 5, it can be known that the safety criteria have the largest weight value, so it can be concluded that Statistics ITS 2018 students prefer safety criteria over the four other criteria when it comes to shipping services. The ranking order of the 4 other criteria is service quality, price, area coverage, dan then the last one is distance. 


\section{E. Weights and Rankings Based on Sub-Criteria for Selecting Alternatives on Shipping Services}

This Each criterion has two sub-criteria, eigen value obtained from the value of level 2 weight for each sub criteria, then the ranking listed in Table 4 below.

\begin{tabular}{lcc}
\multicolumn{3}{c}{ Table 4. Weighting Sub-Criteria In Shipping Service Selection } \\
\hline \multicolumn{1}{c}{$\mathrm{z}$} & \multicolumn{1}{c}{ Eigen } & Rank \\
& 0.343863 & 1 \\
Not wet & 0.160111 & 2 \\
Ontime delivery & 0.14559 & 3 \\
Affordable & 0101074 & 4 \\
Nationwide & 0.076883 & 5 \\
Not broke & 0.057627 & 6 \\
Close to the workspace & 0.051659 & 7 \\
Responsibility & 0.023229 & 8 \\
High & 0.021627 & 9 \\
Island of Java & 0.018338 & 10 \\
Close to home
\end{tabular}

Based on the analysis of eigen value obtained from the value of level 2 weight that shown in Table 6, it can be known that the "not wet" sub criteria have the largest weight value, so it can be concluded that, Statistics ITS 2018 students to choose shipping services prefer "not wet" sub criteria over nine other sub criteria. The ranking order of the 9 other subcriteria is on time delivery, affordable price, nationwide shipping, not broke the goods, shipping office that close to the workspace, responsibility, high price, shipping inside island of Java, and the last one is shipping office that close to home.

\section{F. Selected Alternative Based on Sub-Criteria}

In table 5, it can be found that J\& T shipping service is the most desirable delivery service by statistics ITS students in 2018 for all sub-criteria except sub-criteria close to work and home. In these sub-criteria respondents tend to choose JNE shipping services.

Table 5. Table of Selected Alternative in each Sub-Criteria

\begin{tabular}{ccc} 
Sub Criteria & Eigen Value & Alternative \\
\hline Affordable & 0.05255256 & J\&T \\
High & 0.00814563 & J\&T \\
Close to the workspace & 0.02040866 & JNE \\
Close to home & 0.00678778 & JNE \\
Not broke & 0.02630513 & J\&T \\
Not wet & 0.12300246 & J\&T \\
Responsibility & 0.02277355 & J\&T \\
Ontime delivery & 0.07177236 & J\&T \\
Island of Java & 0.00835902 & J\&T \\
Nationwide & 0.03658818 & J\&T \\
\hline
\end{tabular}

\section{G. Selected Alternative Based on Main Criteria}

In Table 6 it can be known that for distance criteria, respondents tend to prefer JNE while for other criteria such as security, service quality, price and coverage of the region respondents tend to choose J\&T shipping services with the highest criteria weight is security and the lowest weight is distance criteria. Alternative shipping services selected based on the main criteria are as follows. 
Table 6. Table of Selected Alternative in each Criteria

\begin{tabular}{|c|c|c|}
\hline Criteria & Eigen Value & Alternative \\
\hline Safety & 0.149307594 & $\mathrm{~J} \& \mathrm{~T}$ \\
\hline Service Quality & 0.094545908 & $\mathrm{~J} \& \mathrm{~T}$ \\
\hline Price & 0.060698185 & $\mathrm{~J} \& \mathrm{~T}$ \\
\hline Area Coverage & 0.044947201 & $\mathrm{~J} \& \mathrm{~T}$ \\
\hline Distance & 0.027196442 & JNE \\
\hline
\end{tabular}

\section{$H$. Overall selected alternative}

Overall selected alternative shipping services are as follows.

\begin{tabular}{lcc}
\multicolumn{3}{c}{ Table 7. Table of Selected Alternative } \\
\hline \multicolumn{1}{c}{ Alternative } & Eigen Value & Rank \\
\hline J\&T & 0.374881763 & 1 \\
JNE & 0.287677563 & 2 \\
SiCepat & 0.185978297 & 3 \\
Pos Indonesia & 0.151462377 & 4 \\
\hline
\end{tabular}

Based on Table 7, it can be concluded that the best and most in demand shipping service according to Statistics ITS 2018 students are J\&T with a weight 0.3749 and followed by JNE, SiCepat and Pos Indonesia shipping services.

\section{CONCLUSIONS AND FUTURE RESEARCH}

Based on the results of data processing and analysis, it was found that the consistency value of ratio and index in each pairwise matrix $\leq 0.1$ so the analysis of the selection of shipping services by AHP method has optimal results because the $\mathrm{CR}$ value indicates sufficient consistency for decision. As for the results of the analysis of AHP is an alternative shipping services selected from the four alternatives discussed in this study, Statistics ITS 2018 student prefers to use J\&T shipping services, with the priority of safety criteria and sub criteria of goods brought to the destination in conditions not wet. The results of this research can be used as recommendations for any alternative delivery services to improve the quality of the criteria and sub criteria discussed in this research. For further research, other shipping service companies in Indonesia can be used as an alternative so that the results can be compared with existing research.

\section{REFERENCES}

[1] R. Rahmayanti, Analisis Pemilihan Supplier Menggunakan Metode Analytical Hierarhy Process (AHP) (Studi Kasus pada PT. Cazikhal), Surakarta: Universitas Sebelas Maret, pp. 22-82, 2010.

[2] P. Kotler and G. Amstrong, Principles of Marketing, 14th Ed Global, USE: Pearson Education, vol. 6, pp. 47-48, 2012.

[3] F. Tjiptono and G. Chandra, Service, Quality, and Satisfaction, 3rd Ed, Yogyakarta: Andi, pp. 59-69, 2011.

[4] Salkind, N.J. 2016. Statistics for People Who (Think They) Hate Statistics 6th Edition. Thousand Oaks, CA: Sage Publication, 5-18.

[5] Sugiyono, 2014, Metode Penelitian Kuantitatif Kualitatif dan R\&D, Bandung: Alfabeta, 84.

[6] Byun, D.H. 2001. The AHP Approach of Selecting an Automobile Purchase Model. Information and Management, 38, $289-295$.

[7] Saaty, Thomas L, "Decision Making for Leaders 3rd Edition”, University of Pittsburgh, 2012.

[8] Saaty, T. L. 1999. Fundamental of the analytic network process. Pittsburgh: ISAHP, Kobe.

[9] Christopher, martin. 1998. Logistics and Supply Chain Management. London: Prentice Hall.

[10] Mentzer, J.T., Flint, D.J, and Hult, G.T.M. 2001. Logistic service quality asa segmentcustomized process. Journal of marketing, 65(4), pp.82-104.

[11] Okemiri H.A., Nwogbaga, N.E., Nwebonyi, F.N. 2017. Critical Review Of Shipping Service Management System With Empasis To Its Relevance If Adopted In Nigeria. Journal of Multidisciplinary Engineering Science and Technology (JMEST). 